\title{
Influence of phenolic acids on growth and inactivation of Oenococcus oeni and Lactobacillus hilgardii
}

\author{
F.M. Campos, J.A. Couto and T.A. Hogg \\ Escola Superior de Biotecnologia, Universidade Católica Portuguesa, Porto, Portugal
}

Keywords: inactivation, lactic acid bacteria, Lactobacillus hilgardii, Oenococcus oeni, phenolic acids, wine.

\begin{abstract}
F.M. CAMPOS, J.A. COUTO AND T.A. HOGG. 2003.

Aims: To determine the effect of several wine-associated, phenolic acids on the growth and viability of strains of Oenococcus oeni and Lactobacillus hilgardii.

Methods and Results: Growth was monitored in ethanol-containing medium supplemented with varying concentrations of hydroxybenzoic acids ( $p$-hydroxybenzoic, protocatechuic, gallic, vanillic and syringic acids) and hydroxycinnamic acids ( $p$-coumaric, caffeic and ferulic acids). Progressive inactivation was monitored in ethanolcontaining phosphate buffer supplemented in a similar manner to the growth experiments. Hydroxycinnamic acids proved to be more inhibitory to the growth of $O$. oen $i$ than hydroxybenzoic acids. On the other hand, some acids showed a beneficial effect on growth of Lact. hilgardii. p-Coumaric acid showed the strongest inhibitory effect on growth and survival of both bacteria.
\end{abstract}

Conclusions: Most phenolic acids had a negative effect on growth of $O$. oeni, for Lact. hilgardii this effect was only noted for $p$-coumaric acid. Generally, O. oeni was more sensitive to phenolic acid inactivation than Lact. hilgardii. Significance and Impact of the Study: Eight wine-derived, phenolic acids were compared for their effects on wine lactic acid bacteria. Results indicate that phenolic acids have the capacity to influence growth and survival parameters. The differences found between phenolic compounds could be related to their different chemical structures.

\section{INTRODUCTION}

Lactic acid bacteria are a group of Gram-positive, fermentative, aerotolerant bacteria which produce lactic acid as a major end product from carbohydrate metabolism (Stanier et al. 1986). The taxonomy of this group is being reviewed in the light of modern molecular biology (LitopoulosTzanetaki and Tzanetakis 2000).

While not being taxonomically discrete, lactic acid bacteria which can interact with the wine environment are often considered together. These bacteria have the

Correspondence to: Francisco M. Campos, Escola Superior de Biotecnolo-

gia - Universidade Católica Portuguesa, Rua Dr António Bernardino de Almeida, 4200-072 Porto, Portugal

(e-mail:fcampos@morango.esb.ucp.pt). ability to tolerate the stresses of the wine environment, namely low $\mathrm{pH}$, presence of ethanol and sulphur dioxide, low temperature and dilute concentration of nutrients (Fleet 1997).

Lactic acid bacteria can interact with a wine, altering the composition in ways which can, under certain circumstances, be considered beneficial to the quality of the final product. This type of 'positive' interaction includes the malolactic fermentation in which, among other reactions, bacteria decarboxylate L-malic acid to L-lactic acid with subsequent alteration in measured and percieved acidity. Some strains of wine lactic acid bacteria can also cause compositional changes which translate into a range of spoilage conditions, from unacceptable acetic acid and ethyl acetate levels to the 'geranium off-flavour' and 'mousy' taint (Sponholz 1992). 
Oenococcus oeni is the main lactic bacteria responsible for the occurrence of desirable forms of the malolactic fermentation (Cavin et al. 1993), and strains of this species are the major source of malolactic starter cultures used in the wine industry.

Of the lactic acid bacteria implicated in 'spoilage' conditions, strains of Lactobacillus are probably the most cited. In the case of sweet fortified wine, Lact. hilgardii has been identified as a major cause of spoilage (Dicks and van Vuuren 1988; Couto and Hogg 1994; de Revel et al. 1994).

Phenolic compounds are abundant in wine being extracted from the initial grape material (skins, seeds and stalks) and from wood used for storage. Compounds of this family contribute to the sensory characteristics and chemical qualities of wine both directly and indirectly, through their interactions with other molecule types, e.g. proteins, polysaccharides and other polyphenols (Macheix et al. 1990).

The phenolic composition of wines is very complex and includes phenolic (hydroxycinnamic and hydroxybenzoic) acids in concentrations ranging from 100 to $200 \mathrm{mg} \mathrm{l}^{-1}$, depending on the grape variety and vinification process (Reguant et al. 2000). In wine, phenolic acids appear mainly in a combined form: hydroxycinnamic acids form esters with tartaric acid (cynammoyl-tartaric acids) and hydroxybenzoic acids polymerize with other molecules to produce tannins (Macheix et al. 1990). During alcoholic fermentation, free hydroxycynammic acids are released by hydrolysis of tartaric acid esters, but their proportion is relatively low. Despite the structural similarity between acids from the hydroxycinnamic and hydroxybenzoic families, their effect on growth and survival of lactic acid bacteria can be very different. A previous study showed that some free hydroxybenzoic acids can activate cell growth and reduce the malolactic fermentation rate, whereas others are slightly inhibitory (Vivas et al. 1997). Other authors report that some free hydroxycinnamic acids inhibit growth of a variety of microorganisms, including wine-spoilage strains of Lact. collinoides and Lact. brevis (Stead 1993), Escherichia coli, Staphylococcus aureus, Bacillus cereus (Herald and Davidson 1983) and several yeasts (Baranowski et al. 1980; Stead 1993).

Another study showed that alkyl esters of hydroxycinnamic acids can also have an inhibitory effect on Pseudomonas fluorescens (Baranowski and Nagel 1982).

Little work has been published to date concerning the influence of chemical properties of wine phenolic acids and their effect on growth and activity of lactic acid bacteria.

In this work, we investigated the effect of five hydroxybenzoic acids ( $p$-hydroxybenzoic, protocatechuic, gallic, vanillic and syringic acids) and three hydroxycinnamic acids ( $p$-coumaric, caffeic and ferulic acids) on the growth and inactivation of $O$. oeni and Lact. hilgardii.

These compounds exist naturally in wine and were chosen for their different phenolic ring substituents in an attempt to relate the influence of aromatic ring substitution on growth and inactivation of these bacteria.

\section{MATERIALS AND METHODS}

\section{Bacteria and growth conditions}

Lact. hilgardii strain 5, isolated from Port wine by Couto and Hogg (1994), from the ESBUCP (Escola Superior de Biotecnologia da Universidade Católica Portuguesa, Porto, Portugal) culture collection and $O$. oeni commercial strain Viniflora Oenos from Christian Hansen (Hrevidre, Denmark) were used. Lact. hilgardii strain 5 was chosen for being taxonomically representative of the predominant ethanol-tolerant species found in Port wine (Couto and Hogg 1994; Couto 1996).

The liquid growth medium used in this experiment $(\mathrm{MRS} / \mathrm{TJ})$ is a mixture $(50: 50)$ of two commercial media: MRS (de Man, Rogosa and Sharpe) from Biokar Diagnostics (Beauvais, France) and TJ (tomato juice broth) from Difco (Detroit, USA). The initial $\mathrm{pH}$ was adjusted to $4 \cdot 5$ with a concentrated (6 M) hydrochloric acid solution before sterilizing. After sterilization $\left(121^{\circ} \mathrm{C}, 15 \mathrm{~min}\right)$, ethanol $(99.5 \%$ $\mathrm{v} / \mathrm{v}$ ) was added to the medium to obtain a final concentration of $5 \% \mathrm{v} / \mathrm{v}$ ethanol, because this concentration level was found to stimulate growth of both bacteria (Couto 1996).

\section{Influence of phenolic acids on growth of $O$. oeni and Lact. hilgardii}

Cultures were grown aerobically, without agitation, to late exponential phase in MRS/TJ with $5 \% \mathrm{v} / \mathrm{v}$ ethanol at $25^{\circ} \mathrm{C}$, and then transferred to liquid MRS/TJ containing phenolic acid at $0,100,200$ and $500 \mathrm{mg} \mathrm{l}^{-1} \cdot p$-Hydroxybenzoic, protocatechuic (dihydroxybenzoic), gallic (trihydroxybenzoic), vanillic ( $p$-hydroxymethoxybenzoic), syringic ( $p$-hydroxydimethoxybenzoic), $p$-coumaric ( $p$-hydroxycinnamic), caffeic (dihydroxycinnamic) and ferulic ( $p$-hydroxymethoxycinnamic) acids were obtained from Sigma-Aldrich (Steinheim, Germany). Fresh concentrated solutions $\left(10 \mathrm{~g} \mathrm{l}^{-1}\right)$ of phenolic acids were prepared in pure $(99 \cdot 5 \%$ $\mathrm{v} / \mathrm{v})$ ethanol and added to the growth media. The final ethanol concentration of the media was adjusted to $5 \% \mathrm{v} / \mathrm{v}$.

Each individual assay was made in triplicate and incubated aerobically and without agitation at $25^{\circ} \mathrm{C}$. All assays were made simultaneously and the whole experiment was repeated to verify the results.

\section{Growth measurement}

Bacterial growth measurement was determined indirectly by measuring absorbance at $660 \mathrm{~nm}$, using an UV/VIS Unicam 8620 spectrophotometer (Unicam, Cambridge, UK) and 
optical cells of $1 \mathrm{~cm}$ path length. Dilutions with distilled water were made when the optical density value exceeded the linearity limit of Beer-Lambert's law.

\section{Influence of phenolic acids on inactivation of $O$. oeni and Lact. hilgardii}

The effect of different phenolic acids on the inactivation of these lactic bacteria was tested in phosphate buffer solution (at $\mathrm{pH} 4.5$ ) with $9 \% \mathrm{v} / \mathrm{v}$ ethanol. This concentration level was chosen because it represents an ethanol stress while generating inactivation kinetics which are measurable over a convenient time period. Cultures in stationary phase (grown aerobically, without agitation, for four days in MRS/TJ with $5 \%(\mathrm{v} / \mathrm{v})$ ethanol at $\left.25^{\circ} \mathrm{C}\right)$ were centrifuged $(10 \mathrm{~min}$, $3000 \mathrm{~g}$ ). The biomass was washed with phosphate buffer $\left(\mathrm{KH}_{2} \mathrm{PO}_{4}, 0 \cdot 15 \mathrm{M}, \mathrm{pH} 4 \cdot 5\right)$ containing $5 \%(\mathrm{v} / \mathrm{v})$ ethanol and centrifuged again.

Cells were resuspended in phosphate buffer containing $5 \% \mathrm{v} / \mathrm{v}$ ethanol and transfered to $250 \mathrm{ml}$ Erlenmeyer flasks, stirred magnetically and immersed in a thermostatted water bath at $25^{\circ} \mathrm{C}$. Each flask contained $100 \mathrm{ml}$ of phosphate buffer containing $9 \%(\mathrm{v} / \mathrm{v})$ ethanol and phenolic acid at 0 , 100,200 or $500 \mathrm{mg} \mathrm{l}^{-1}$.

Samples were collected at 1, 15, 30, 60 and $90 \mathrm{~min}$ (in the case of $O$. oeni) and at $0,1,3,5$ and $7 \mathrm{~h}$ (in the case of Lact. hilgardii) after inoculation of the phosphate buffer, properly diluted and plated in duplicate on MRS/TJ media containing 20.0 $\mathrm{g} \mathrm{l}^{-1}$ Agar MC2 (Lab M, Bury, UK) and $5 \%$ ethanol. Plates were incubated aerobically at $25^{\circ} \mathrm{C}$ for 5-7 days.

The whole experiment was repeated for each phenolic acid and bacterium to confirm the results.

\section{RESULTS}

\section{Effect of phenolic acids on growth of $\boldsymbol{O}$. oeni}

All phenolic acids tested in this experiment were inhibitory for the growth of $\mathrm{O}$. oeni, although the inhibitory effect was stronger with hydroxycinnamic acids than with hydroxybenzoic acids. This inhibitory effect increased with the concentration of phenolic acids and caused a decrease in both the maximal growth rate and maximal cell density when compared to the control culture (Fig. 1).

In the case of the hydroxycinnamic acids, the inhibitory effect was greatest for caffeic and $p$-coumaric acids and least for ferulic acid (Fig. 1a,b,c).

In the case of the hydroxybenzoic acids, the inhibitory effect was greatest with protocatechuic and $p$-hydroxybenzoic acids and least with gallic acid. Vanillic and syringic acids showed an intermediate effect (Fig. 1d,e,f).

\section{Effect of phenolic acids on growth of Lact. hilgardii}

All phenolic acids tested in this experiment did not affect significantly the growth of Lact. hilgardii when present at $100 \mathrm{mg} \mathrm{l}^{-1}$ (Fig. 2a,d).

In the case of hydroxycinnamic acids, at $200 \mathrm{mg} \mathrm{l}^{-1}$ there was a decrease in the growth rate and a slight increase in the final cell concentration of the cultures, when compared to the control (Fig. 2b). At $500 \mathrm{mg} \mathrm{l}^{-1}$ there was an increase in the lag phase and a decrease in the growth rate of the cultures. This effect was stronger with $p$-coumaric acid than with caffeic and ferulic acids. Cultures supplemented with caffeic and ferulic acids reached higher final cell concentrations than the control culture (Fig. 2c).

In the case of hydroxybenzoic acids at $500 \mathrm{mg} \mathrm{l}^{-1}$, gallic acid showed no effect on growth of Lact. hilgardii, while vanillic and syringic acids caused a decrease in growth rate, comparatively with the control culture (Fig. 2f). At this concentration, $p$-hydroxybenzoic acid showed an inhibitory effect similar to $p$-coumaric acid (decrease in growth rate) and protocatechuic acid a similar effect to ferulic acid (decrease in growth rate and increase in cell concentration).

\section{Influence of phenolic acids on inactivation of Lact. hilgardii}

At $100 \mathrm{mg} \mathrm{l}^{-1}$, only $p$-coumaric and gallic acids showed a slight inhibitory effect on Lact. hilgardii (Fig. 3a, Table 1). At higher concentrations, several acids had the same effect on the bacteria. At $500 \mathrm{mg} \mathrm{l}^{-1}, p$-coumaric acid caused a sharp decrease of viable bacteria, inactivating most cells after $7 \mathrm{~h}$ (Fig. 3c, Table 1). At this concentration level, all the phenolic acids tested showed an inhibitory action, except vanillic and $p$-hydroxybenzoic acids. $p$-Coumaric acid caused the highest decrease in viability at all concentrations tested.

\section{Influence of phenolic acids on inactivation of 0 . oeni}

Results obtained indicate that at concentration of $100 \mathrm{mg} \mathrm{l}^{-1}$ there was no noticeable inactivation effect on $O$. oeni for any phenolic acid (Fig. 3d, Table 2). At $200 \mathrm{mg}^{-1} p$-coumaric and syringic acids inactivated $O$. oeni, causing a noticeable decrease of viable cells after $90 \mathrm{~min}$ (Fig. 3e, Table 2). At $500 \mathrm{mg} \mathrm{l}^{-1}$, several phenolic acids caused inactivation of the bacteria, $p$-coumaric and syringic acids having the highest effects. Ferulic, caffeic, $p$-hydroxybenzoic and vanillic acids did not have significant inactivation effects on the bacteria, even at $500 \mathrm{mg}^{-1}$ (Fig. 3f, Table 2). 

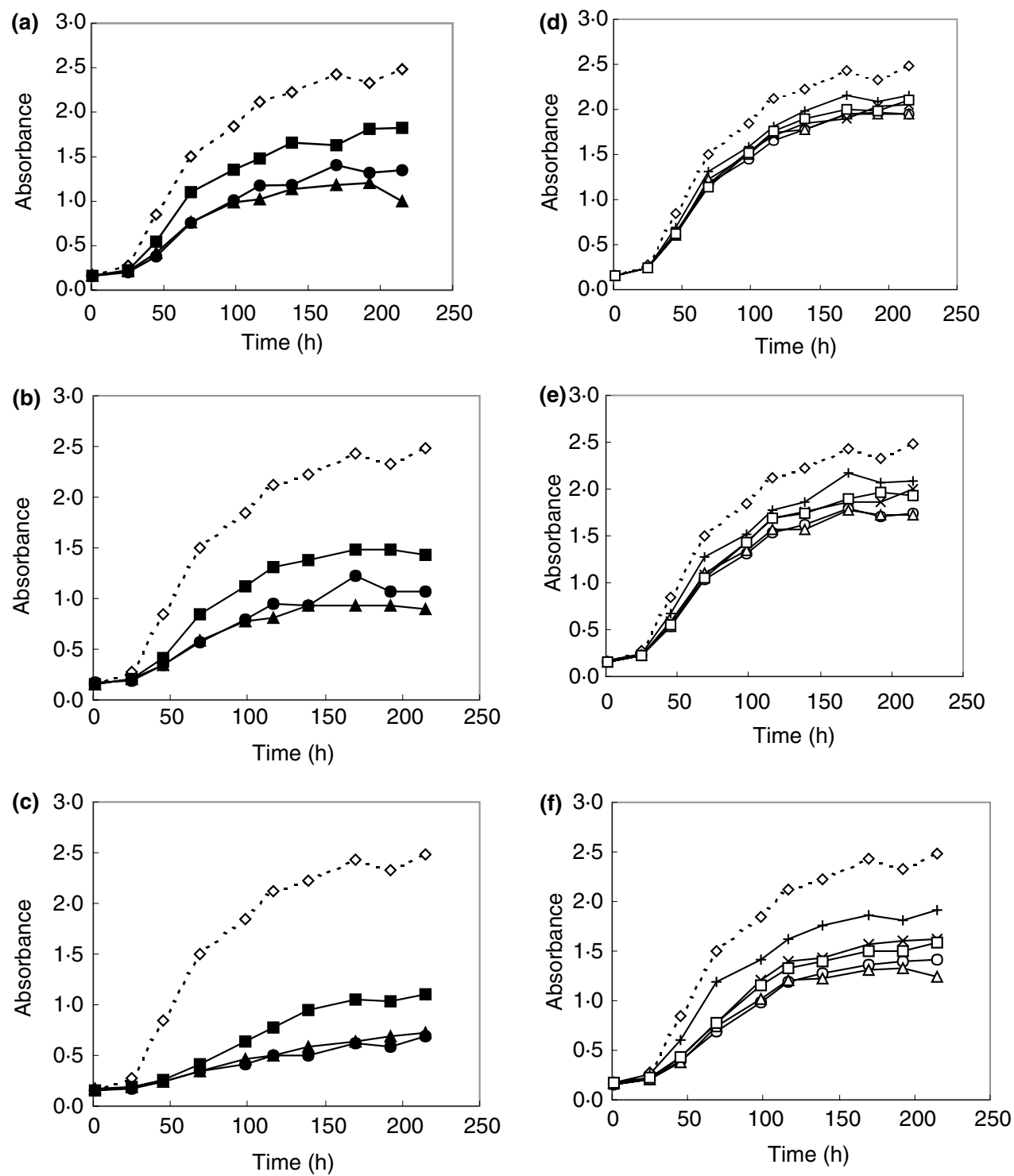

Fig. 1 Growth curves of Oenococcus oeni $\mathrm{VF}$ in MRS/TJ media $\left(\mathrm{pH} 4 \cdot 5,5 \% \mathrm{v} / \mathrm{v}\right.$ ethanol at $\left.25^{\circ} \mathrm{C}\right)$ supplemented with hydroxycinnamic acids at:

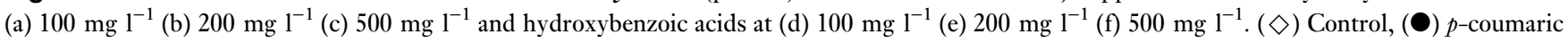
acid, $(\mathbf{\Delta})$ caffeic acid, $(\boldsymbol{\square})$ ferulic acid, $(\bigcirc)$-hydroxybenzoic acid, $(\Delta)$ protocatechuic acid, $(+)$ gallic acid $(\square)$ vanillic acid, $(\times)$ syringic acid; each point represents the average value of three determinations (RSD $<=3 \%$ )

\section{DISCUSSION}

The results indicate that phenolic acids influence the growth of O. oeni $\mathrm{VF}$ and Lact. hilgardii 5 , in growth media. This influence can be either positive or negative in terms of growth stimulation, depending on the bacterial species, the specific phenolic acid used and its concentration.

All phenolic acids tested were inhibitory for the growth of $\mathrm{O}$. oeni $\mathrm{VF}$, even at the lowest concentration tested $\left(100 \mathrm{mg} \mathrm{l}^{-1}\right)$, although the inhibitory effect was stronger with hydroxycinnamic acids than with hydroxybenzoic acids. Caffeic and $p$-coumaric were the most inhibitory compounds, having effects of similar magnitude on the growth of this bacterium. On the other hand, gallic acid had the least inhibitory effect of all phenolic acids tested.

Results obtained with Lact. hilgardii 5 show that, at low concentrations (up to $200 \mathrm{mg} \mathrm{l}^{-1}$ ) hydroxycinnamic acids led to higher final cell concentrations in spite of a decrease in growth rate and a lengthening of the initial lag phase. These effects were also observable at $500 \mathrm{mg} \mathrm{l}^{-1}$, except for $p$-coumaric acid, which had a strong negative effect on 

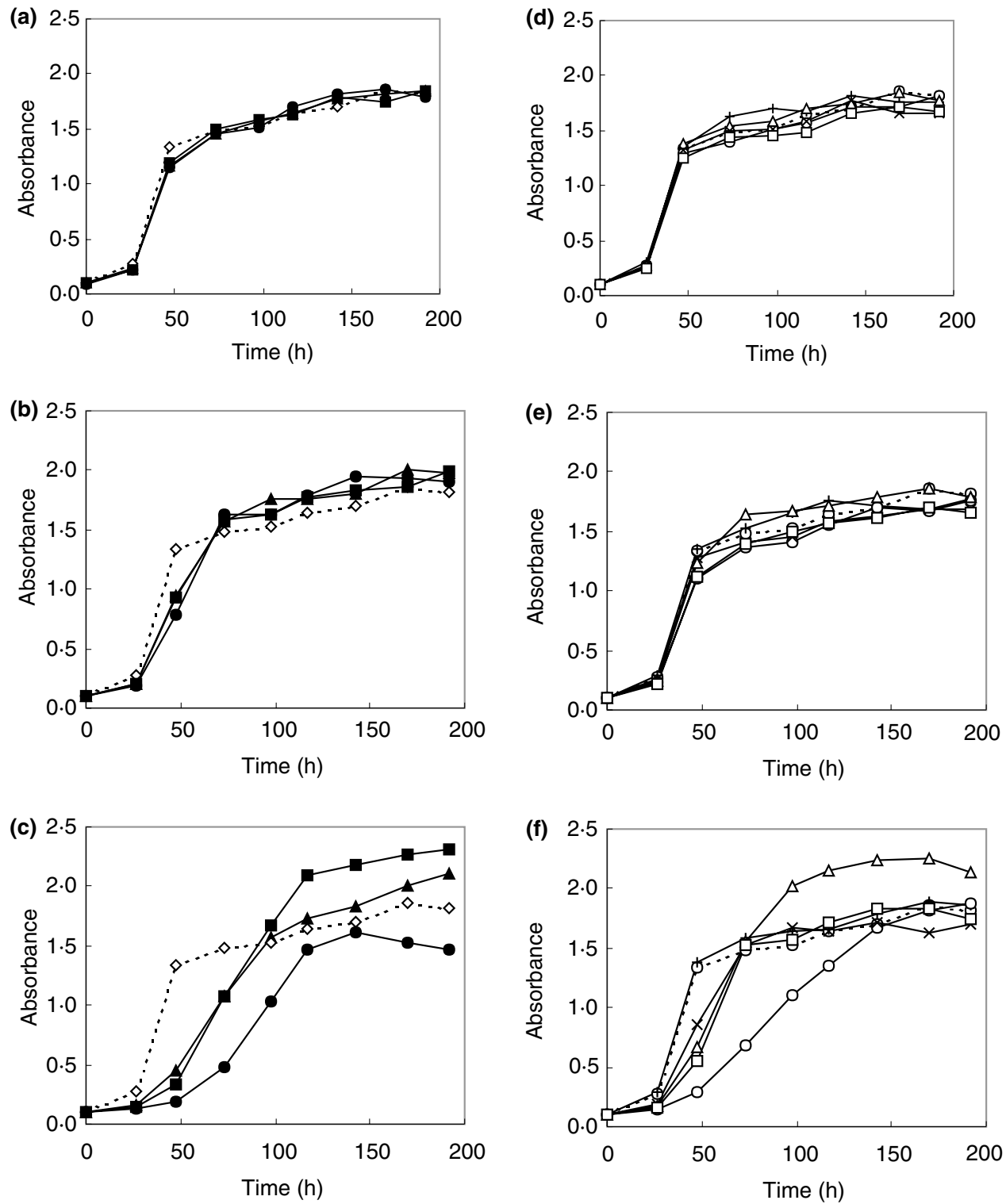

Fig. 2 Growth curves of Lactobacillus hilgardii 5 in MRS/TJ media $\left(\mathrm{pH} 4 \cdot 5,5 \% \mathrm{v} / \mathrm{v}\right.$ ethanol at $\left.25^{\circ} \mathrm{C}\right)$ supplemented with hydroxycinnamic acids at: (a) $100 \mathrm{mg} \mathrm{l}^{-1}$, (b) $200 \mathrm{mg} \mathrm{l}^{-1}$, (c) $500 \mathrm{mg} \mathrm{l}^{-1}$ and hydroxybenzoic acids at (d) $100 \mathrm{mg} \mathrm{l}^{-1}$, (e) $200 \mathrm{mg} \mathrm{l}^{-1}$, (f) $500 \mathrm{mg} \mathrm{l}^{-1}$. ( $\left.\diamond\right)$ Control,

(๑) p-coumaric acid, $(\boldsymbol{\Delta})$ caffeic acid, $(\boldsymbol{\square})$ ferulic acid, $(\bigcirc)$-hydroxybenzoic acid, $(\Delta)$ protocatechuic acid, $(+)$ gallic acid, $(\square)$ vanillic acid, $(\times)$ syringic acid; each point represents the average value of three determinations ( $\mathrm{RSD}<=3 \%$ )

bacterial growth. These results agree, in essence, with those reported previously in experiments conducted with other lactobacilli (Stead 1993).

Phenolic acids have different antioxidant (oxygen radical scavenger) capacities which are related to their aromatic ring substituents (Natella et al. 1999). This antioxidant effect is stronger with cinnamic than with benzoic acids and is highest with dihydroxy (caffeic and protocatechuic) and $p$-hydroxymethoxy (ferulic and vanillic) substituents. This antioxidant capacity of these compounds might be involved in some way in the stimulation effect of these compounds on growth of Lact. hilgardii 5.

Some lactobacilli can metabolize hydroxycinnamic acids, originating 2-hydroxyphenylpropionic acids which can, in turn, be decarboxylated yielding substituted $p$-ethyl phenols (Cavin et al. 1993; Stead 1993; Chatonnet et al. 1995, 1997). These compounds are often described as off-flavours in wine and have very low sensory thresholds (Chatonnet et al. 1997). The metabolism of certain hydroxycinnamic acids could also be a possible explanation for the beneficial effect 

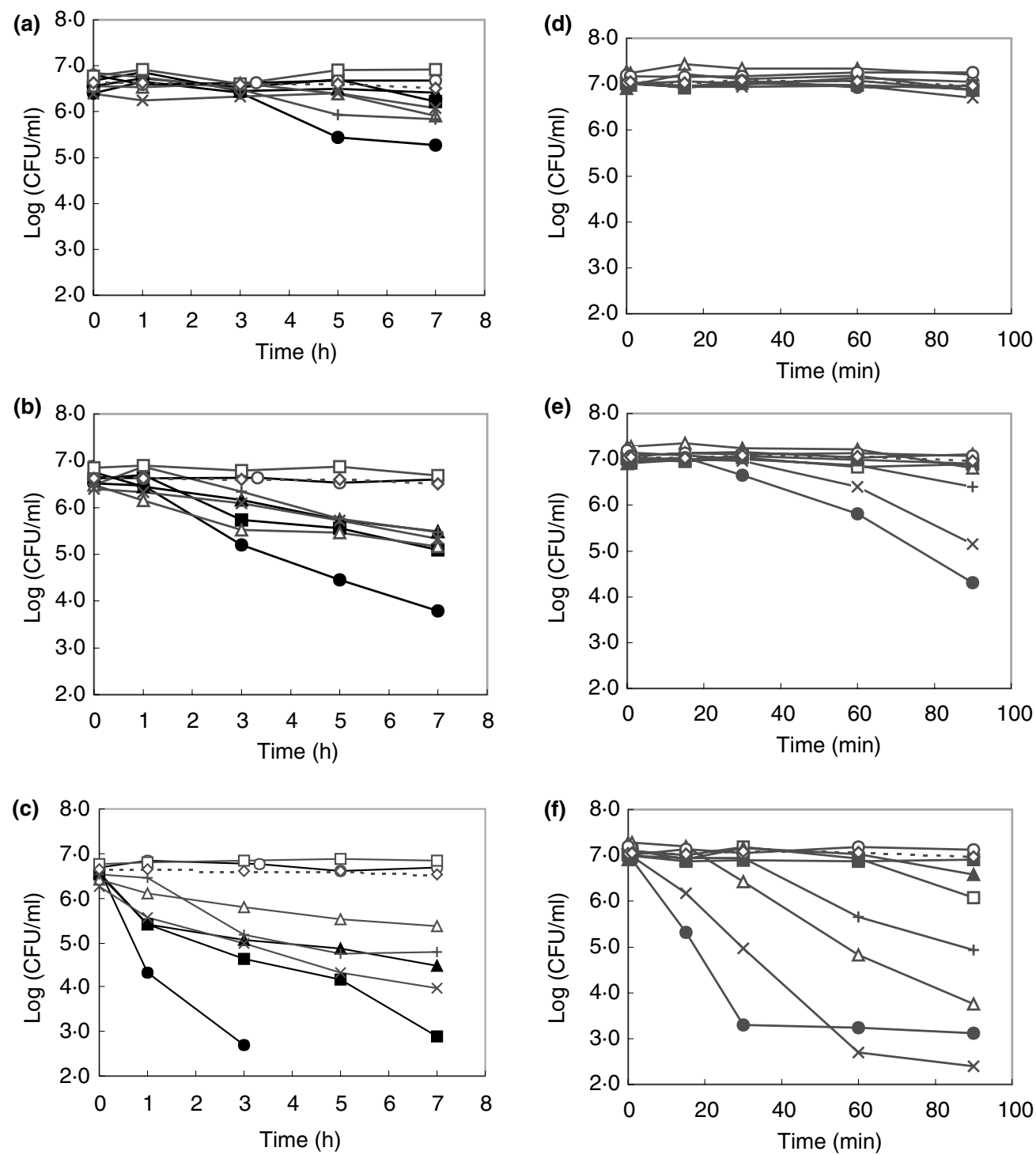

Fig. 3 Inactivation curves of wine lactic acid bacteria in phosphate buffer ( $\mathrm{pH} 4 \cdot 5,9 \% \mathrm{v} / \mathrm{v}$ ethanol at $25^{\circ} \mathrm{C}$ ) supplemented with phenolic acids. Inactivation of Lactobacillus hilgardii 5 at (a) $100 \mathrm{mg}^{-1}$ (b) $200 \mathrm{mg} \mathrm{l}^{-1}$ (c) $500 \mathrm{mg}^{-1}$ phenolic acid concentration and Oenococus oeni $\mathrm{VF}$

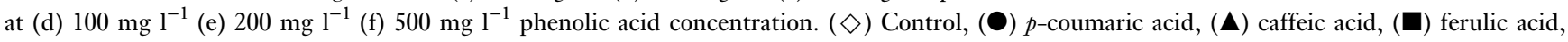
(○) p-hydroxybenzoic acid, $(\triangle)$ protocatechuic acid, $(+)$ gallic acid, $(\square)$ vanillic acid, $(\times)$ syringic acid

of these compounds on growth of Lact. hilgardii 5. Further investigations are necessary to evaluate the potential of this bacterium to produce volatile $p$-ethyl phenols and to understand the biological motives of these conversions.

Hydroxycinammic acids, due to their propenoic side chain, are much less polar than the corresponding hydroxybenzoic acids, and this property might facilitate the transport of these molecules across the cell membrane, which might be related in turn to the stronger inhibitory effect of hydroxycinammic acids in the experiments performed with O.oeni. The polarity of the molecule alone, however, cannot explain the different effects of the phenolic acids. In fact, the most inhibitory hydroxycinammic and hydroxybenzoic acids to bacterial growth were $p$-coumaric and $p$-hydroxybenzoic acids, respectively, exhibiting intermediate polarities within each group. Some authors suggest that an equilibrium between solubility in both lipid and aqueous phases could be necessary to ensure the inhibitory effect of hydroxycinammic acids on bacterial growth (Herald and Davidson 1983).

Inactivation experiments confirmed the apparent toxicity of $p$-coumaric acid to both bacteria. Syringic, gallic and 
Table 1 Effect of phenolic acid concentration on inactivation of Lactobacillus hilgardii 5 in phosphate buffer $\left(\mathrm{pH} 4 \cdot 5,9 \% \mathrm{v} / \mathrm{v}\right.$ ethanol) at $25^{\circ} \mathrm{C}$

\begin{tabular}{|c|c|c|c|c|c|c|c|c|}
\hline \multirow[b]{2}{*}{ Concentration $\left(\mathrm{mg} \mathrm{l}^{-1}\right)$} & \multicolumn{2}{|l|}{0} & \multicolumn{2}{|l|}{100} & \multicolumn{2}{|l|}{200} & \multicolumn{2}{|l|}{500} \\
\hline & $\log n / \log n_{0} *$ & SD & $\log n / \log n_{0}$ & SD & $\log n / \log n_{0}$ & SD & $\log n / \log n_{0}$ & SD \\
\hline Protocatechuic acid & $1 \cdot 00$ & $\pm 0 \cdot 01$ & $0 \cdot 93$ & $\pm 0 \cdot 05$ & $0 \cdot 80$ & $\pm 0 \cdot 04$ & $0 \cdot 76$ & $\pm 0 \cdot 08$ \\
\hline Gallic acid & $1 \cdot 00$ & $\pm 0 \cdot 01$ & $0 \cdot 85$ & $\pm 0 \cdot 09$ & $0 \cdot 85$ & $\pm 0 \cdot 02$ & $0 \cdot 73$ & $\pm 0 \cdot 05$ \\
\hline Vanillic acid & $1 \cdot 01$ & $\pm 0 \cdot 01$ & $1 \cdot 02$ & $\pm 0 \cdot 01$ & 0.97 & $\pm 0 \cdot 05$ & $1 \cdot 01$ & $\pm 0 \cdot 03$ \\
\hline Caffeic acid & $1 \cdot 00$ & $\pm 0 \cdot 01$ & 0.96 & $\pm 0 \cdot 02$ & $0 \cdot 81$ & $\pm 0 \cdot 02$ & 0.68 & $\pm 0 \cdot 00$ \\
\hline Ferulic acid & 0.95 & $\pm 0 \cdot 04$ & 0.94 & $\pm 0 \cdot 01$ & $0 \cdot 78$ & $\pm 0 \cdot 01$ & $0 \cdot 44$ & $\pm 0 \cdot 03$ \\
\hline
\end{tabular}

${ }^{*} n_{0}$, initial viable cell number; $n$, viable cell number after $7 \mathrm{~h}$; SD, standard deviation; values represent the average of four determinations; $\dagger$ value obtained after $3 \mathrm{~h}$.

Table 2 Effect of phenolic acid concentration on inactivation of Oenococcus oeni $\mathrm{VF}$ in phosphate buffer ( $\mathrm{pH} 4 \cdot 5,9 \% \mathrm{v} / \mathrm{v}$ ethanol) at $25^{\circ} \mathrm{C}$

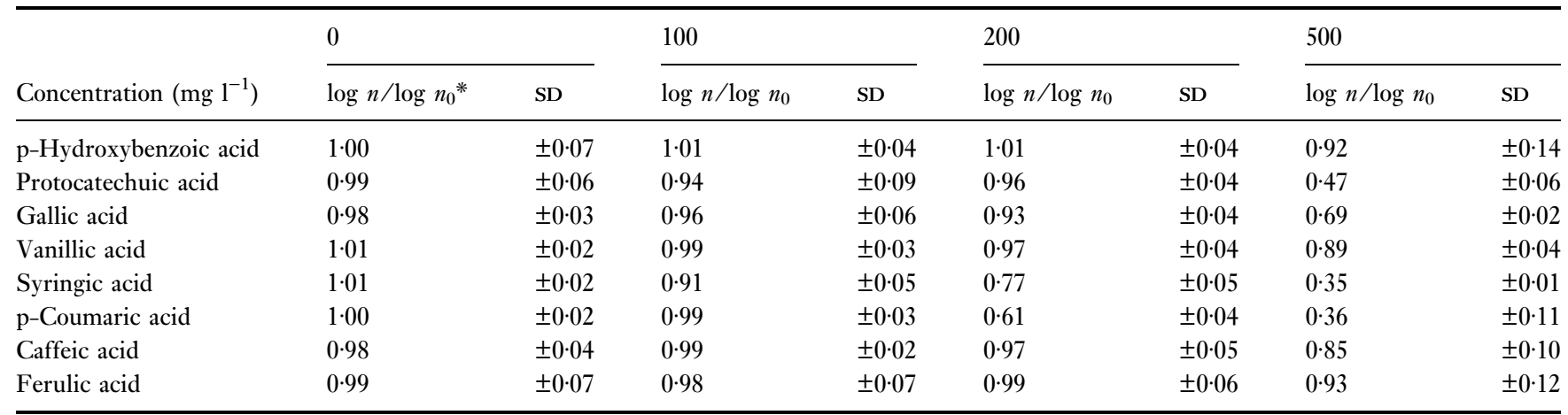

${ }^{*} n_{0}$, initial viable cell number; $n$, viable cell number after $90 \mathrm{~min}$; SD, standard deviation; values represent the average of four determinations.

protocatechuic acid also had an inactivation effect on these organisms.

Generally, Lact. hilgardii 5 was much more resistant than O. oeni $\mathrm{VF}$ to inactivation by phenolic acids at $9 \%$ ethanol $(\mathrm{v} / \mathrm{v})$ which could be explained by the fact that the latter is much less ethanol-tolerant than the former. The kinetics of inactivation of Lact. hilgardii were determined over a longer period of time than that of $O$. oeni because of its higher tolerance to ethanol.

The inhibitory effect of some phenolic acids apparently cannot be explained by the simple adsorption to cell walls (Vivas et al. 1997). Other mechanisms proposed include a role as cytoplasmic poisons, due to their putative ability to enter the cell in undissociated form, dissociating in the cytoplasm and hence being progressively accumulated (Reguant et al. 2000). It is known, of course, that generically phenolic compounds can damage the bacterial cell membrane, causing leakage of intracellular constituents (McDonnell and Russell 1999). Hydroxycinammic acid derivatives are known to interact with the membrane lipids of taste papillae in the tongue, causing a bitter sensation
(Macheix et al. 1990). This bitterness is caused presumably by a neutralization of the membrane electric potential, following penetration of the molecule. A similar effect could occur in bacterial cell membranes, affecting their energy metabolism. Some polyphenols can interact with carbohydrates and proteins by hydrogen bonding, hydrophobic and ionic interactions (McManus et al. 1985). Interaction with cell enzymes could also be a possible explanation for the inhibitory effect of phenolic acids.

The above conclusions are largely speculation, which shows that a general lack of knowledge exists concerning this specific subject. That phenolic acids have the capacity to influence growth and survival parameters has been shown. The effects these compounds might exert on other activity parameters, such as metabolism, are also beginning to be described (Vivas et al. 1997; Reguant et al. 2000). The specific mechanisms which underlie these effects are far from being described fully.

Current work is being focused on the specific mechanisms responsible for inactivation or growth stimulation of wine lactic acid bacteria by phenolic compounds. 


\section{ACKNOWLEDGEMENTS}

F.M. Campos would like to thank FCT for the grant Praxis XXI BD19909/99.

\section{REFERENCES}

Baranowski, J.D., Davidson, P.M., Nagel, C.W. and Branen, A.L. (1980) Inhibition of Saccharomyces cerevisiae by naturally occurring hydroxycinnamates. Fournal of Food Science 45, 592-594.

Baranowski, J.D. and Nagel, C.W. (1982) Inhibition of Pseudomonas fluorescens by hydroxycinammic acids and their alkyl esters. Fournal of Food Science 47, 1587-1589.

Cavin, J.F., Andioc, V., Etievant, P.X. and Divies, C. (1993) Ability of wine lactic acid bacteria to metabolize phenol carboxylic acids. American Fournal of Enology and Viticulture 44, 76-80.

Chatonnet, P., Dubourdieu, D. and Boidron, J.N. (1995) The influence of Brettanomyces/Dekkera sp., yeasts and lactic acid bacteria on the ethylphenol content of red wines. American Fournal of Enology and Viticulture 46, 463-468.

Chatonnet, P., Viala, C. and Dubourdieu, D. (1997) Influence of polyphenolic components of red wines on the microbial synthesis of volatile phenols. American fournal of Enology and Viticulture 48, 443448.

Couto, J.A. (1996) Studies on diversity, taxonomy and physiology of ethanol tolerant Lactobacilli isolated from Douro fortified wine $P h D$ Thesis, Escola Superior de Biotecnologia da Universidade Catolica Portuguesa, Porto, Portugal.

Couto, J.A. and Hogg, T.A. (1994) Diversity of ethanol-tolerant lactobacilli isolated from Douro fortified wine: clustering and identification by numerical analysis of electrophoretic protein profiles. Fournal of Applied Bacteriology 76, 487-491.

Dicks, L.M.T. and van Vuuren, H.J.J. (1988) Identification and physiological characteristics of heterofermentative strains of Lactobacillus from South African red wines. Fournal of Applied Bacteriology 64, 505-513.

Fleet, G.H. (1997) Wine. In Food Microbiology Fundamentals and Frontiers ed. Doyle, M.P., Beuchat, L.R. and Montville, T.J., pp. 682. Washington DC: ASM Press.
Herald, P.J. and Davidson, P.M. (1983) Antibacterial activity of selected hydroxycinammic acids. Fournal of Food Science 48, 13781379 .

Litopoulos-Tzanetaki, E. and Tzanetakis, N. (2000) Fermented milks. In Encyclopedia of Food Microbiology ed. Robinson, R.R., Batt, C.A. and Patel, P.D., Vol. 2, pp. 774, 777. London: Academic Press.

Macheix, J.J., Fleuriet, A. and Billot, J. (1990) Fruit Phenolics, pp. 323332. Boca Raton, Florida: CRC Press.

McDonnell, G. and Russell, A.D. (1999) Antiseptics and disinfectants: activity, action, and resistance. Clinical Microbiology Reviems 12, 147-179.

McManus, J.P., Davis, K.G., Beart, J.E., Gaffney, S.H. and Lilley, T.H. (1985) Polyphenol interactions. Part 1. Introduction: some observations on the reversible complexation of polyphenols with proteins and polysaccharides. Fournal of the Chemical Society Perkin Transactions II, 1429-1438.

Natella, F., Nardini, M., Di Felice, M. and Scaccini, C. (1999) Benzoic and cinnamic acid derivatives as antioxidants: structureactivity relation. Fournal of Agriculture and Food Chemistry 47, 1453-1459.

Reguant, C., Bordons, A., Arola, L. and Rozès, N. (2000) Influence of phenolic compounds on the physiology of Oenococcus oeni from wine. Fournal of Applied Microbiology 88, 1065-1071.

de Revel, G., Capela, A.B. and Hogg, T. (1994) A pre-spoilage marker for bacterial activity in fortified wines, conversion of L-malic acid to L-lactic acid. Letters in Applied Microbiology 18, 329-332.

Sponholz, W.R. (1993) Wine spoilage by microorganisms. In Wine Microbiology and Biotechnology ed. Fleet G., pp. 404-413. Chur: Harwood Academic Publishers.

Stanier, R.Y., Ingraham, J.L., Wheelis, M.L. and Painter, P.R. (1986) General Microbiology, 5th edn, pp. 496-497. London: MacMillan Press.

Stead, D. (1993) The effect of hydroxycinnamic acids on the growth of wine-spoilage lactic acid bacteria. Fournal of Applied Microbiology 75, 135-141.

Vivas, N., Lonvaud-Funel, A. and Glories, Y. (1997) Effect of phenolic acids and anthocyanins on growth, viability and malolactic activity of a lactic acid bacterium. Food Microbiology 14, 291-300. 